\title{
Gender participation and decision making process in farming and household activities: A case of Pali district of Rajasthan, India
}

\author{
M.L. MEENA AND AISHWARYA DUDI
}

Received: 02.06.2017; Revised: 15.10.2017; Accepted: 29.10.2017

See end of the paper for authors' affiliations M.L. MEENA

ICAR-CAZRI, Krishi Vigyan Kendra, PALI-MARWAR (RAJASTHAN) INDIA

Email : mlmeenacazri@gmail.com
ABSTRACT : Participation in decision making process especially in economic activities is an indication of empowerment. The present study attempts to investigate the level of women economic empowerment in resource-poor farm families by analyzing their extent of participation in decision making on farm and household related economic activities. The study was conducted in six blocks Pali district of Rajasthan taking a random sample of 180 resource poor farm families. Both husband and wife of the families were personally interviewed by pretested structured interview schedule. Spearman's rank-difference correlation was used to measure the extent of agreement between husband's and wife's responses. The study revealed that wives played a major role to jointly decide purchasing or hiring of land (44.44-48.33\%), selling of produce (35.56$37.78 \%$ ) and borrowing for agriculture (25.00-30.56\%). Decisions for milking and processing of milk, utilization of dung and sale of milk and milk products were dominantly taken by wives 68.33 $\%, 56.67 \%$ and $39.44 \%$, respectively, where purchase and sale of animals, type and number of animals to be kept and adoption of new animal husbandry practices were mainly decided jointly 32.78-36.67\%, 32.78-35.56\% and 24.44-25.00 per cent, respectively. Household economic decisions on building new house, household purchasing, education of children, selection of occupation for children and financial activities were mainly taken jointly 39.44-42.78\%, 33.33-36.67 \%, 26.31$31.67 \%, 25.00-31.67 \%$ and $23.22-27.22$ per cent, respectively. The findings of the study indicated higher level of women economic empowerment in animal husbandry and household sectors.

KEY WORDS: Women empowerment, Decision making, Resource-poor farm family, Spearman's rankdifference correlation

— HOW TO CITE THIS PAPER : Meena, M.L. and Dudi, Aishwarya (2017). Gender participation and decision making process in farming and household activities: A case of Pali district of Rajasthan, India. Asian J. Home Sci., 12 (2) : 496-502, DOI: 10.15740/HAS/AJHS/12.2/496-502. 